\title{
Neolovenula alluaudi (Guerne and Richard, 1890) (Calanoida: Diaptomidae: Paradiaptominae): first record in Italy and review of geographical distribution
}

\author{
Giuseppe ALFONSO, ${ }^{*}$ Genuario BELMONTE \\ Laboratorio di Zoogeografia e Fauna, Dipartimento di Scienze e Tecnologie Biologiche Ambientali - Di.S.Te.B.A., Università del \\ Salento, Lecce, Italy. \\ *Corresponding author: giuseppe.alfonso@unisalento.it
}

\begin{abstract}
As part of recent limnological campaigns in Puglia region (South-Eastern Italy), 217 temporary and permanent ponds were studied. The diaptomid calanoid copepod Neolovenula alluaudi (Guerne and Richard, 1890) was collected in eight of these ponds. These findings represent the first record of the species in Italy. Morphological features are provided with original drawings, which are compared with currently available descriptions. Environmental variables were recorded in order to provide information on the ecological preferenda of the species in its Italian occurrence sites; in addition, the co-occurring crustacean fauna was identified and reported for each pond. A review of the available literature allowed us to determine more accurately the chorology of the species and to propose a biogeographical hypothesis concerning its distribution. An updated map of the species'distribution including the new Italian sites is presented and we provide evidence to support the idea that the current chorotype of $\mathrm{N}$. alluaudi is the result of an association of the Saharan and Turanic-European-Mediterranean chorotypes.
\end{abstract}

Key words: Copepoda, Italian fauna, biogeography, inland waters, zooplankton, species distribution.

Received: November 2012. Accepted: January 2013.

\section{INTRODUCTION}

The inland water copepod Neolovenula alluaudi (Guerne and Richard, 1890) is currently the only known species contained in the genus Neolovenula Gauthier, 1938 (Dussart and Defaye, 2002; Boxshall and Halsey, 2004; Walter, 2012). The genus Neolovenula as well as Paradiaptomus G.O. Sars, 1895, Lovenula Schmeil, 1898, and Metadiaptomus Methuen, 1910, belongs to the calanoid subfamily Paradiaptominae Kiefer, 1932 (Calanoida, Diaptomidae) (Rayner, 1999).

Paradiaptominae currently comprises 24 species (Boxshall and Halsey, 2004), most of which (20) are endemic to Africa. Two species - Metadiaptomus asiaticus (Ulyanin, 1875) and Paradiaptomus greeni (Gurney, 1906) - show an exclusively non-African distribution, and two other species - Metadiaptomus chevreuxi (Guerne and Richard, 1894) and N. alluaudi - have been found in Northern Africa as well as outside of Africa. The distribution of the Paradiaptominae suggests that they are probably of Afrotropical origin (Boxshall and Jaume, 2000).

Neolovenula alluaudi, like M. chevreuxi, has expanded towards the Euro-Mediterranean area (Dussart and Defaye, 2002). Specifically, $N$. alluaudi has always been considered to be a circum-Mediterranean species (Guerne and Richard, 1891; Tollinger, 1911; Kiefer, 1958, 1978a, 1978b; Dussart, 1967, 1989; Pesce and Maggi, 1981; Petkovski, 1983; Jaume 1989-90; Einsle, 1993; Rayner
1999, 2000), even though the species has started to be detected outside the Mediterranean area [e.g. Niger and Chad (Dussart, 1989), Russia, Iran and Turkmenistan (Borutzky et al., 1991)]. A slightly different view of the species' distribution was supplied by Miracle (1982), who defined N. alluaudi as a Mediterranean species of southern origin. Miracle (1982) and Pretus (1991) stressed also the disjunct distribution of the species in Southern Europe, as evidenced by its absence in France, the Italian peninsula, the Tyrrhenian islands and most of Central Europe.

Online databases report contrasting information. Fauna Europaea (www.faunaeur.org) shows a disjunct distribution of the species in Europe, reporting its occurrence in the Iberian peninsula (Spain and Portugal including the Canary islands), Crete, the Balkans (Greece, Republic of Macedonia, Bulgaria), Romania, Hungary, Slovakia, Moldova and Ukraine. In addition, the same database reports the species as occurring in Northern Africa and in the Near East. In contrast, the GBIF database (www.gbif.org) reports the species only for Spain. The BioFresh database (www.freshwaterbiodiversity.eu) defines $N$. alluaudi as an Afrotropical species.

Numerous references to the distribution of this species are currently available, but they often refer uncritically to past literature, without checking the exact locations of the occurrence sites. Consequently, some information on the distribution of this species could be inaccurate or even misleading. Nevertheless, what appears evident from the literature is the species' broad distribution, from Northern 
Africa to parts of Southern Europe, the Middle East and the Sarmato-Turkmenistan steppes. Information on the wide distribution of $N$. alluaudi has been available since the first few years (Ekman, 1904a, 1904b) following its description (Guerne and Richard, 1890), but it soon became evident that the species was not ubiquitous (Gauthier, 1938). However, its large distribution range was justified by some authors with reference to the ecology of the species, which is considered to be fairly euriecious and euryhaline (Dumont, 1979; Borutzky et al., 1991; Alonso, 1998; Rayner, 1999).

The presumed absence of $N$. alluaudi from some areas (including Italy, in the centre of the Mediterranean area) could have been due to two reasons, which are not mutually exclusive: i) the ecological preferences of the species ii) the different sampling efforts in the different areas.

This paper analyses the case of Italy, where N. alluaudi has not been reported to date, and therefore has always been presumed to be absent from this area. Italian inland water calanoid fauna has been studied since the end of the nineteenth century, focusing mainly on the northern and central parts of the country (see Stoch, 2006; Marrone et al., 2011, and references therein). Researches on calanoid fauna in the Southern peninsular Italy (Belmonte et al., 2006; Alfonso and Belmonte, 2008, 2011) as well as in Sicily (Marrone et al., 2006a, 2006b, and references therein) has been intensified only in the last few years. As a result, several updates have recently been made to the Italian fauna and consequently to the distribution of $\mathrm{N}$. alluaudi on a larger scale.
We report updates on the calanoid fauna of Puglia region, presenting the first Italian record of $N$. alluaudi. Morphological features are provided in original drawings and compared with those in the literature. In addition, we discuss the available data on the distribution of the species and provide a revised map of the records in order to identify the actual chorotype of the species.

\section{METHODS}

\section{Collection and processing of samples and environmental data}

Following the guidelines of a recent research project on the Mediterranean temporary ponds (European Commission, 1992) in Puglia (Alfonso et al., 2011), the sampling effort was intensified in order to achieve a more detailed characterisation of the crustacean fauna of the sites studied.

In Puglia, 96 sites were added to the 121 sites reported in a previous study (Alfonso and Belmonte, 2011). Here, we supply data referring to the eight sites where $N$. alluaudi was collected (Tab. 1). The eight sites were sampled at least twice during their hydroperiods, which are mainly in winter 2012 (Supplementary Tab. 1).

Environmental variables (water temperature, $\mathrm{pH}$, conductivity, oxygen, and total dissolved solids) were measured with a Hanna Instruments HI9828 multi-probe (Hanna Instruments, Villafranca Padovana, Italy). Water transparency was determined using a turbidity tube (Dahlgren et al., 2004).

Zooplankton samples were collected using a plankton

Tab. 1. Locations in Puglia (Southern Italy) where Neolovenula alluaudi has been detected.

\begin{tabular}{|c|c|c|c|c|c|c|c|}
\hline Code & Site name & Location & Latitude $(\mathrm{N})$ & Longitude (E) & Altitude (m asl) & $\begin{array}{c}3170^{*} \\
\text { Plant communities }\end{array}$ & $\begin{array}{c}\text { Protection } \\
\text { measures }\end{array}$ \\
\hline PU042 & Bosco Mangiato & $\begin{array}{l}\text { Martina Franca } \\
\text { (Taranto) }\end{array}$ & $40^{\circ} 44^{\prime} 27^{\prime \prime}$ & $17^{\circ} 14^{\prime} 42^{\prime \prime}$ & 432 & & $\begin{array}{l}\text { Murge di Sud Est } \\
\text { Natura } 2000\end{array}$ \\
\hline PU047 & Taverna Nuova 1 & $\begin{array}{l}\text { Ruvo di Puglia } \\
\text { (Bari) }\end{array}$ & $40^{\circ} 59^{\prime} 42^{\prime \prime}$ & $16^{\circ} 18^{\prime} 12^{\prime \prime}$ & 608 & & $\begin{array}{l}\text { Alta Murgia } \\
\text { National Park }\end{array}$ \\
\hline PU048 & Taverna Nuova 2 & $\begin{array}{l}\text { Ruvo di Puglia } \\
\text { (Bari) }\end{array}$ & $40^{\circ} 59^{\prime} 39^{\prime \prime}$ & $16^{\circ} 17^{\prime} 56^{\prime \prime}$ & 600 & & $\begin{array}{c}\text { Alta Murgia } \\
\text { National Park }\end{array}$ \\
\hline PU126 & Madonna del Lago & $\begin{array}{c}\text { San Donato di Lecce } \\
\text { (Lecce) }\end{array}$ & $40^{\circ} 16^{\prime} 41^{\prime \prime}$ & $18^{\circ} 10^{\prime} 04^{\prime \prime}$ & 66 & Verbena supina & none \\
\hline PU167_I & $\begin{array}{l}\text { Masseria Ciminiero } \\
\text { (pond) }\end{array}$ & $\begin{array}{c}\text { Andria } \\
\text { (Barletta-Andria-Trani) }\end{array}$ & $41^{\circ} 01^{\prime} 05^{\prime \prime}$ & $16^{\circ} 11^{\prime} 17^{\prime \prime}$ & 582 & & $\begin{array}{l}\text { Alta Murgia } \\
\text { National Park }\end{array}$ \\
\hline PU167_II & $\begin{array}{l}\text { Masseria Ciminiero } \\
\text { (flooded field) }\end{array}$ & $\begin{array}{c}\text { Andria } \\
\text { (Barletta-Andria-Trani) }\end{array}$ & $41^{\circ} 01^{\prime} 07^{\prime \prime}$ & $16^{\circ} 11^{\prime} 18^{\prime \prime}$ & 582 & & $\begin{array}{l}\text { Alta Murgia } \\
\text { National Park }\end{array}$ \\
\hline PU168 & Goglia & $\begin{array}{c}\text { Minervino Murge } \\
\text { (Barletta-Andria-Trani) }\end{array}$ & $41^{\circ} 05^{\prime} 07^{\prime \prime}$ & $16^{\circ} 06^{\prime} 52^{\prime \prime}$ & 519 & Verbena supina & $\begin{array}{l}\text { Alta Murgia } \\
\text { National Park }\end{array}$ \\
\hline PU170 & Masseria Lotito & $\begin{array}{c}\text { Minervino Murge } \\
\text { (Barletta-Andria-Trani) }\end{array}$ & $41^{\circ} 04^{\prime} 39^{\prime \prime}$ & $16^{\circ} 07^{\prime} 26^{\prime \prime}$ & 522 & & $\begin{array}{l}\text { Alta Murgia } \\
\text { Natura } 2000\end{array}$ \\
\hline
\end{tabular}

$N$, north; E, east.

${ }^{\circ}$ This column refers to the plant species characterising Mediterranean temporary ponds priority habitat as listed in Council Directive 92/43/EC (European Commission, 1992). 
net ( $24 \mathrm{~cm}$ diameter, $125 \mu \mathrm{m}$ mesh size) horizontally towed from side to side in each pond. Samples were fixed in situ with $96 \%$ ethanol. Calanoid species were identified according to the keys by Dussart $(1967,1989)$, Kiefer (1978a, 1978b), Petkovski (1983), Stella (1984), Einsle (1993), and Rayner (1999). Co-occurring taxa in each site were identified following the guides of Margaritora (1985) and Alonso (1996) for Cladocera, Einsle (1993) for Cyclopoida, and Meisch (2000) for Ostracoda.

Drawings of the main morphological features of specimens of both sexes (Fig. 1) collected at the site PU170 (Tab. 1 and Supplementary Tab. 1) on the $26^{\text {th }}$ April 2012 were prepared using a compound microscope equipped with a camera lucida. Specimens used for drawings were previously treated with hot lactic acid for the tissue digestion. Several voucher specimens from the same population have been deposited in the collection of the Smithsonian Institution (National Museum of Natural History) in Washington DC with the accession number USNM \#1197894, courtesy of Dr. Chad Walter.

\section{Review of the literature}

A thorough review of the literature reporting $\mathrm{Ne}$ olovenula alluaudi was conducted. Most of the papers were supplied by the Smithsonian Institution (National Museum of Natural History of Washington DC, courtesy of Dr. Lana Ong) or, when possible, by directly contacting the authors. All records documented in the literature were critically checked and reported on a map showing their exact geographic positions. The distribution map was prepared using ArcGIS9-ArcMap v 9.2, based on the WGS1984 geographic coordinate system. Records which reported generically a country or large geographical area without specifying accurate coordinates or locations were considered doubtful. A chorotype for $N$. alluaudi was then proposed in accordance with Vigna Taglianti et al. (1999), considering the cumulative records shown on the outlined map (Fig. 2).

\section{RESULTS}

\section{Synonyms}

Neolovenula alluaudi (Guerne and Richard, 1890) (Fig. 1) has several synonyms, namely:

Diaptomus Alluaudi Guerne (de) and Richard 1890;

Diaptomus unguiculatus Daday, 1890;

Diaptomus Lorteti Barrois, 1891;

Diaptomus Alluaudi Guerne (de) and Richard 1891; Richard, 1893; Guerne (de) and Richard 1896; Gjorgewič, 1907; Kiefer, 1927;

Diaptomus alluaudi Giesbrecht and Schmeil, 1898; Tollinger, 1911;

Diaptomus allaudi Ekman, 1904a; 1904b;

Metadiaptomus alluaudi Gurney, 1929;

Paradiaptomus lorteti Gauthier, 1931;
Lovenula (Neolovenula) Alluaudi Kiefer, 1932; Rose and Vaissière, 1952/53;

Lovenula (Neolovenula) alluaudi Gauthier, 1933; Ortiz, 1957; Damian-Georgescu，1966; Naidenow，1973; Kiefer, 1978a; Pesce and Maggi, 1981; Dussart and Defaye, 1983; Petkovsky, 1983; Borutzky et al., 1991; Einsle, 1993; Alonso, 1998; Demeter and Marrone, 2009; Neolovenula alluaudi Gauthier, 1938; Dussart, 1967; Dussart, 1980; Miracle, 1982; Dumont and Verheye, 1984; Rayner, 1999; Rayner, 2000; Dussart and Defaye, 2002; Boxshall and Halsey, 2004; Samchyshyna, 2011; Lovenula alluaudi Ulomsky, 1941; Margalef, 1953; Brtek, 1977; Ilies, 1978; Zaitsev and Alexandrov, 1998; Ustaoğlu, 2004; Yevdokimov and Yermokhin, 2009; Lovenula Alluaudi François, 1949; Margalef, 1956; Paradiaptomus desertorum Manuilova, 1951; Lovenula (Allolovenula) Alluaudi Nógrády, 1956; Neolovenulla Alluaudi Pljakic and Zivkovic, 1958; Paradiaptomus (Lovenula) alluaudi Dussart, 1989; Defaye et al., 2000;

Paradiaptomus alluaudi Rayner, 1992.

\section{Morphology}

The female (Fig. 1A) is larger than the male (Fig. 1G). Specimens studied have two outer spines on the third exopodal article of the first leg (Fig. 1E). The male right antennula has three post-geniculate articles, the last one with a beak-like terminal extension (Fig. 1H). All these characters are typical of Paradiaptominae (Rayner, 1999). Maxilliped not typically scythe-shaped (Fig. 1F). Female urosome has three somites (Fig. 1B) and the genital somite is expanded dorso-ventrally (Fig. 1C). Female fifth leg endopod is reduced and lacks distal setae (Fig. 1D). Male right fifth leg (Fig. 1I) has a reduced endopod, the second exopodal article is narrowed proximally. Male left fifth leg (Fig. 1I) lacks endopod; exopod bears a long curved spiniform process, accompanied by a slender seta, on the last article. Male right antennula with spiniform processes on the articles 8, 10, 11, 12, 13 is given in Fig. 1H. Male urosome with five somites is represented in Fig. 1L.

The main morphological features of the Neolovenula alluaudi specimens collected in the Puglia ponds (Fig. 1) broadly correspond to those of descriptions and drawings found in the literature (Daday, 1890; Barrois, 1891; Kiefer, 1958, 1978a; Damian-Georgescu, 1966; Dussart, 1967, 1989; Pesce and Maggi, 1981; Petkovski, 1983; Jaume, 1989-90; Einsle, 1993). However, the chetotaxis on the twelfth article of the male right antennula (Fig. 1F) is characterised by a thin seta and a small spine, as already observed by Borutzky et al. (1991), Dussart (1989), Kiefer $(1958,1978 \mathrm{a}, 1978 \mathrm{~b})$, but it is in contrast with the description by Damian-Georgescu (1966), who reported two long and thin setae, and Rayner (1999), who reported no spine (nor spiniform process) on the same article. 


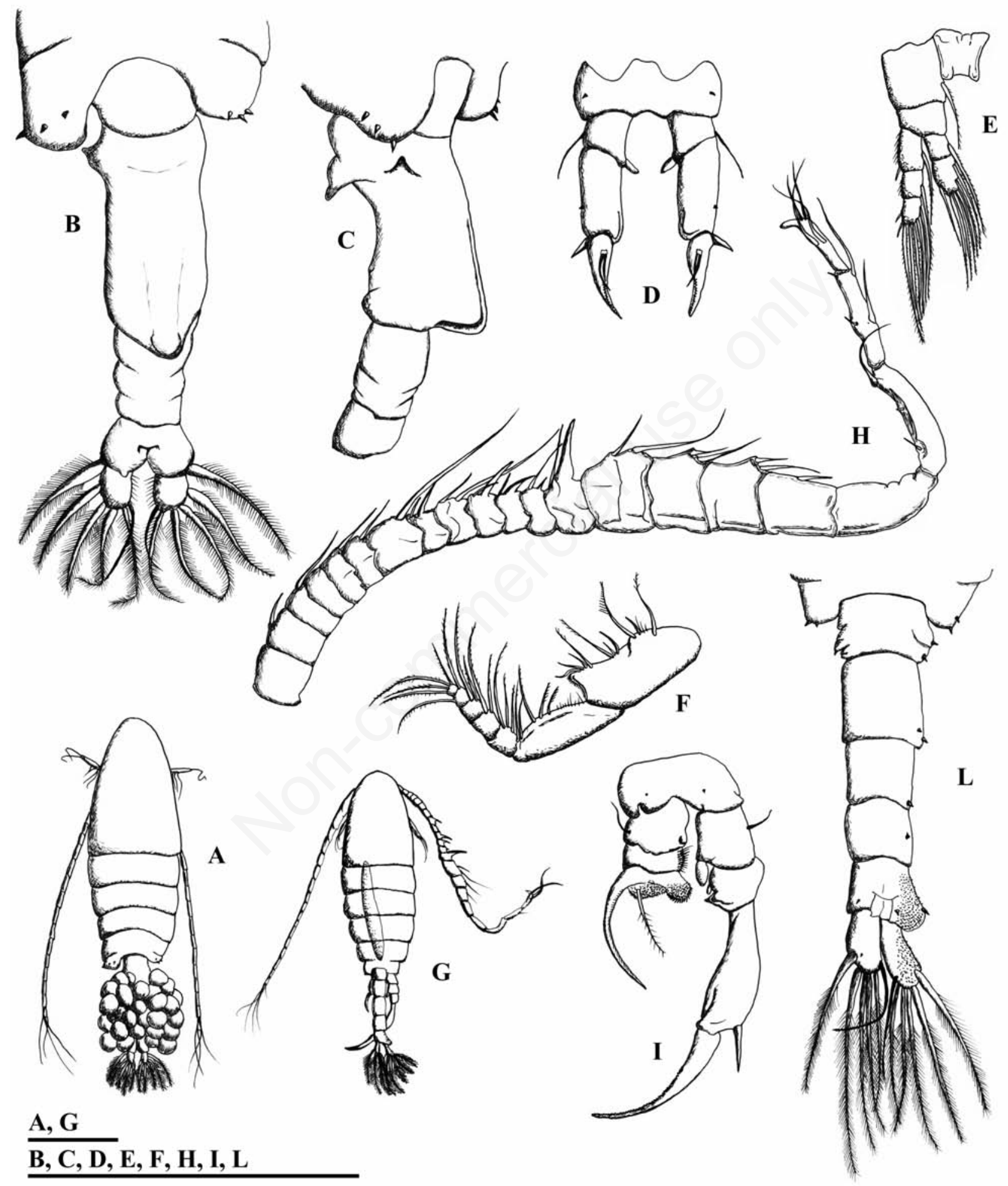

Fig. 1. Neolovenula alluaudi (Guerne and Richard, 1890). Female: A, habitus; B, urosome (dorsal view); C, urosome (lateral view); D, fifth leg; E, first leg; F, maxilliped. Male: G, habitus; H, right antennula; I, fifth leg; L, urosome. Scale bars: $500 \mu \mathrm{m}$. 
The size of the Puglia specimens falls within the range provided by the bibliography (males $1100-2000 \mu \mathrm{m}$; females $1500-2200 \mu \mathrm{m})$, with average values of $1572 \pm 109 \mu \mathrm{m}$ for males (113 specimens from all 8 studied sites) and $1911 \pm 140$ $\mu \mathrm{m}$ for females ( 89 specimens from all 8 studied sites).

\section{Environmental and biological features of the occurrence sites in Italy}

Neolovenula alluaudi (Fig. 1) was collected in Italy for the first time in autumn 2010 in a pond called Madonna del Lago (site code: PU126) in the Salento peninsula (Puglia). The species was later collected from seven other sites in Puglia, Murgian plateau (Tab. 1 and detail of Fig. 2). This finding updates the checklist of Italian inland water Calanoida (Stoch, 2006; Marrone et al., 2011) to 31 species (one Temoridae, one Pseudodiaptomidae, one Centropagidae, two Paradiaptominae, 26 Diaptominae), 14 of which are present in Puglia (Alfonso and Belmonte, 2011).

\section{Ecology and distribution}

With the single exception of the site in the Salento peninsula (66 m asl), N. alluaudi was detected at moder- ately high altitude, in seven sites on the Murgian plateau ranging between 430 and $610 \mathrm{~m}$ asl. Most of these sites lie in the Alta Murgia National Park.

Of the eight occurrence sites, five are characterised by a long hydroperiod that sometimes lasts more than a year depending on rainfall patterns, precipitation usually ranging from 500 to $750 \mathrm{~mm}$ per year (Zito et al., 1991) in the Murgia area and the Salento peninsula. The other three ponds are typical temporary water bodies. Moreover, sites PU168 and PU126 were identified as Mediterranean temporary ponds (European Commission, 1992) due to the presence of Verbena supina plant communities (Tab. 1). The registered environmental variables of the water (Supplementary Tab. 1) showed broad ranges of values and the relatively low number of ponds involved does not allow for statistical analysis or the identification of well-defined ecological patterns. Water temperature ranged between 5.95 and $27.46^{\circ} \mathrm{C}$; $\mathrm{pH}$ between 7.40 and 11.15 ; electric conductivity between 131 and $824 \mu \mathrm{S} / \mathrm{cm}$; dissolved oxygen between 0.30 and $9.50 \mathrm{mg} / \mathrm{L}$; turbidity between $2 \mathrm{~cm}$ and more than $1 \mathrm{~m}$.

Cumulative data on the crustacean fauna of each pond where $N$. alluaudi was found in Puglia are shown

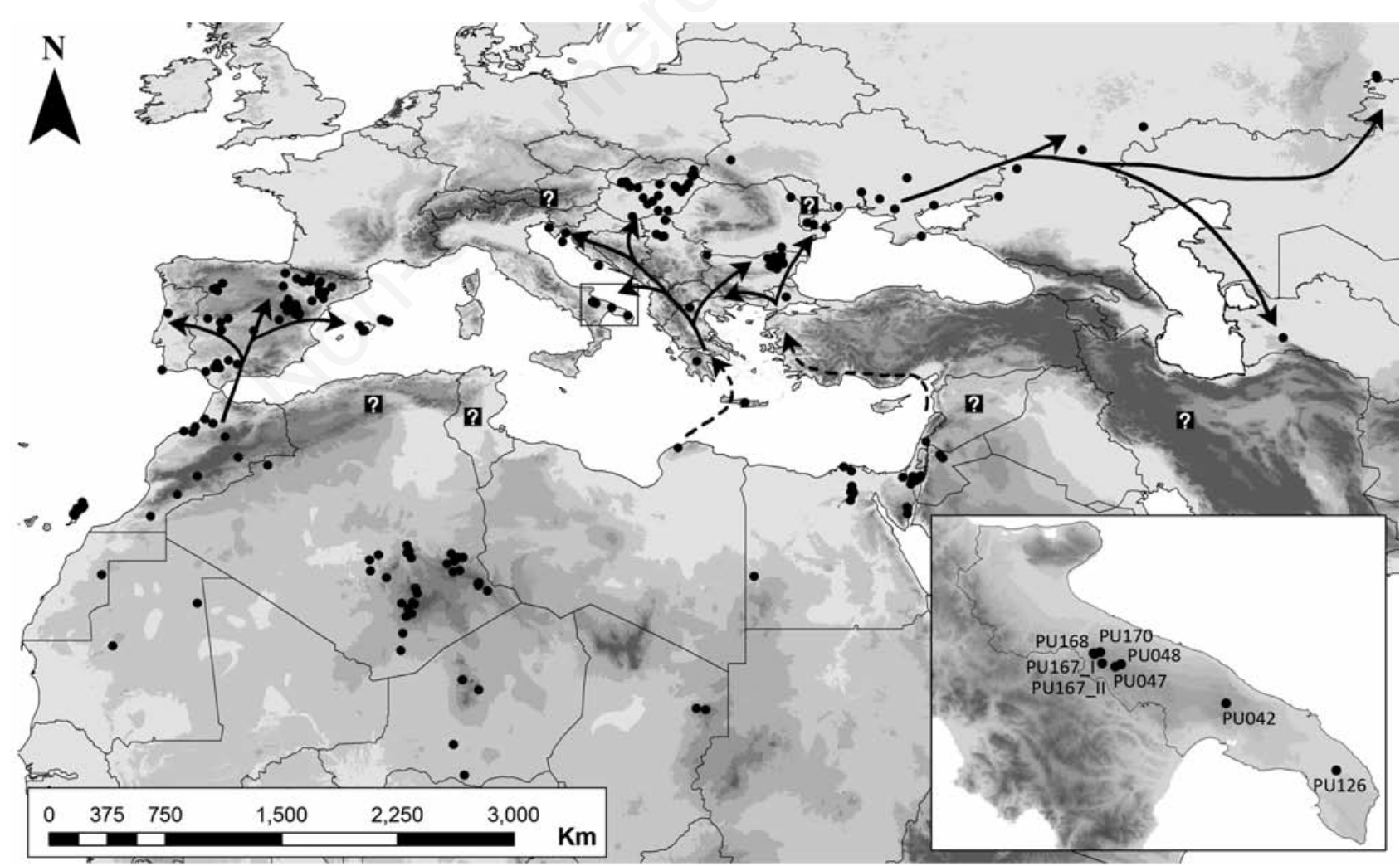

Fig. 2. Documented sites where Neolovenula alluaudi has been reported. Question marks refer to the doubtful records. The hypothesised main routes of dispersal outside Africa are represented by arrows, while the dotted ones refer to the two alternative eastern expansion routes. In the bottom right box, first records in Italy (Puglia region) are shown. 
in Tab. 2. The studied ponds host from 6 (PU170) to 14 species (PU168). The most frequent co-occurring crustacean species are Ceriodaphnia quadrangula (O.F. Müller, 1785) among the Cladocera, Cyclops divergens Lindberg, 1936 among the Cyclopoida, Eucypris gr. virens (Jurine, 1820) and Plesiocypridopsis newtoni (Jurine, 1820) among the Ostracoda.

In four of the ponds characterised by a longer hydroperiod, $N$. alluaudi was the only occurring calanoid. In contrast, in the three strictly temporary ponds the species co-occurs with other calanoids (Tab. 2). The case of PU168, in which $N$. alluaudi was found to co-occur with four other calanoid species, is remarkable for the large number of calanoids synchronically co-occurring in the same pond. Pond PU167_II - often connected to the temporary pond PU167_I - was the only long hydroperiod site in which $N$. alluaudi co-occurred with another calanoid species.

\section{Review of the literature sites}

A total of 88 papers dealing with the distribution of $N$. alluaudi or reporting its presence somewhere, were found. Data were extracted from each paper (Supplementary Tab. 2) and mapped, leading to a final list of 262 sites in total (Fig. 2). Of these, 248 sites are documented in the bibliography, eight sites are the new ones reported for Italy in the present study and six sites are cited in the literature but are regarded by us as doubtful. Excluding the doubtful records and including the new data reported by the present study, 89 records occur in Northern Africa, 156 in Europe and 11 in the Middle East. Most of the African records are located in the Hoggar mountains (Southern Algeria), Aïr (Niger), Ennedi (Chad), and the Western Maghreb (Morocco). Its distribution in northern Africa is also characterised by evident empty areas mainly coinciding with the desert environment of the Sahara, and sites along the Mediterranean coast are limited to the Nile delta and Cyrenaica. Outside Africa, $N$. alluaudi has been recorded in the Iberian peninsula and Balearic islands, Crete, the Balkans, the Pannonian basin, Southern Ukraine, Southern Russia, Turkmenistan, Israel, the Golan heights and the Sinai peninsula.

Literature on calanoid fauna referring to the empty areas was also checked. For example, Brteck (1977) and Rayner $(1999,2000)$ reported $N$. alluaudi generically in Tunisia, without specifying the exact location. However, no dated (Gurney, 1909; Gauthier, 1928; Dumont et al., 1979) or recent papers (Turki and Turki, 2010) referring to Tunisian Copepoda have never reported $N$. alluaudi. A similar case is Austria, a country for which the species was reported by Damian-Georgescu (1966) and Naidenow (1966) with no any additional specification. However, no further papers attesting this record were found, and Gaviria et al. (2002) do not report $N$. alluaudi in the
Calanoida checklist in their inventory of Austrian aquatic organisms. Considering the size of the region, the Middle East suffers from a dearth of studies in the limnological field. The few data available for this area (Supplementary Tab. 2) are mainly restricted to the Sinai peninsula, Israel, and the Golan heights. A report for Turkey is limited to Thrace (Ustaoğlu, personal communication). The easternmost documented sites occur in Western Turkmenistan and in Russia close to the Urals, in the Chelyabinsk oblast (Borutzky et al., 1991).

\section{DISCUSSION}

\section{Occurrence of Neolovenula alluaudi in Italy}

The present study is the first one to record $N$. alluaudi in Italy, and the second to record Paradiaptominae in Italian fauna after the finding of Metadiaptomus chevreuxi in Sicily (Marrone and Naselli-Flores, 2005). There are no significant morphological features among the Italian specimens (Fig. 1) that might distinguish them from the other populations depicted in the literature.

It is not easy to verify whether $N$. alluaudi colonised Puglia recently because of the lack of an adequate number of past studies in the area and long-term time-series monitoring. Of the eight sites hosting N. alluaudi in Puglia, three had already been sampled once or twice (Supplementary Tab. 1) by Alfonso and Belmonte (2011), but neither $N$. alluaudi nor any other calanoid species were detected there. The failure to detect the species previously in those sites stresses the need to sample the same pond several times (in the same ponding phase, and in different years) in order to obtain the most accurate information on the biological community.

Nevertheless, if we consider that the populations closest to the Puglia sites are in the Balkans, it is probable that Puglia populations are more closely related to the Balkan ones than the African ones. The pseudo-steppe environment, widespread in the Murgian uplands, appears to be the most suitable environment for the species in Southern Italy. Indeed, $N$. alluaudi is frequently found in steppic areas in other countries too, both warm (as in the Ebro valley in Spain and the Balearic islands) and cold (as in the Pannonian basin, Ukraine and South-Western Russia). Alonso (1998) identified well-defined associations of crustaceans among the freshwater communities in the steppic areas in Spain. These are characterised by the calanoids Mixodiaptomus incrassatus (G.O. Sars, 1903) and $N$. alluaudi, the cladocerans Ceriodaphnia quadrangula (O.F. Müller, 1785) and Daphnia obtusa Kurz, 1874, and sometimes the anostracan Streptocephalus torvicornis Waga, 1842, a similar situation as found in ponds with $N$. alluaudi in Puglia.

It is well-known that Puglia fauna is distinct from the rest of Italy (Minelli et al., 2006) because of its affinities 
Tab. 2. Cumulative data on crustacean fauna comprising Neolovenula alluaudi in the eight ponds of Puglia.

\begin{tabular}{|c|c|c|c|c|c|c|c|c|}
\hline & \multicolumn{8}{|c|}{ Pond code } \\
\hline & PU042 & PU047 & PU048 & PU126 & PU167_I & PU167_II & PU168 & PU170 \\
\hline \multicolumn{9}{|l|}{ Branchiopoda } \\
\hline \multicolumn{9}{|l|}{ Anostraca } \\
\hline \multicolumn{9}{|l|}{ Chirocephalidae } \\
\hline Chirocephalus diaphanus Prévost, 1803 & & & & & + & + & + & \\
\hline \multicolumn{9}{|l|}{ Streptocephalidae } \\
\hline Streptocephalus cf torvicornis Waga, 1842 & & & & & & & + & \\
\hline \multicolumn{9}{|l|}{ Cladocera } \\
\hline \multicolumn{9}{|l|}{ Chydoridae } \\
\hline Chydorus sphaericus O.F. Müller, 1785 & & + & & & & & + & + \\
\hline Pleuroxus letourneuxi (Richard, 1888) & & & & + & + & + & + & \\
\hline \multicolumn{9}{|l|}{ Daphniidae } \\
\hline Ceriodaphnia laticaudata P.E. Müller, 1867 & + & & & & & & & \\
\hline Ceriodaphnia quadrangula (O.F. Müller, 1785) & & + & + & + & + & + & + & + \\
\hline Daphnia (Ctenodaphnia) atkinsoni Baird, 1859 & & & & & + & + & & \\
\hline Daphnia (Ctenodaphnia) chevreuxi Richard, 1896 & & & & & & & + & + \\
\hline Daphnia (Daphnia) gr. galeata-hyalina & & + & & & & & & \\
\hline Daphnia (Daphnia) obtusa Kurz, 1874 & + & + & + & & & & & + \\
\hline Simocephalus vetulus (O.F. Müller, 1776) & & + & + & + & & & & \\
\hline \multicolumn{9}{|l|}{ Macrothricidae } \\
\hline Macrothrix groenlandica Lilljeborg, 1900 & & & & & & + & + & \\
\hline \multicolumn{9}{|l|}{ Moinidae } \\
\hline Moina micrura Kurz, 1874 & & & & + & + & & & \\
\hline
\end{tabular}

Copepoda

Calanoida

Diaptomidae

Diaptominae

Arctodiaptomus (Arctodiaptomus) wierzejskii (Richard, 1888)

Diaptomus (Chaetodiaptomus) cyaneus Gurney, 1909

Hemidiaptomus (Occidodiaptomus) ingens (Gurney, 1909)

Mixodiaptomus incrassatus (G.O. Sars, 1903)

Paradiaptominae

Neolovenula alluaudi (Guerne and Richard, 1890)

Cyclopoida

Cyclopidae

Cyclops divergens Lindberg, 1936

Diacyclops lubbocki (Brady, 1869)

Eucyclops (Eucyclops) serrulatus (Fischer, 1851)

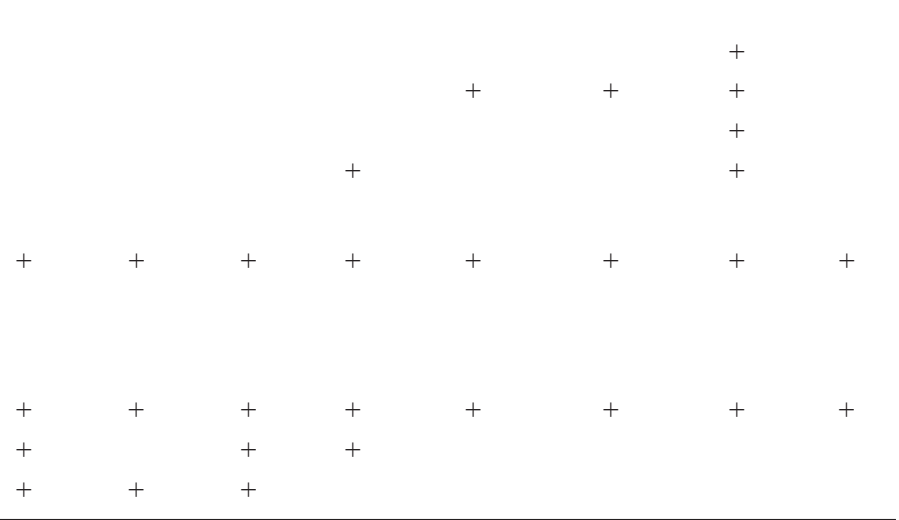

Ostracoda

Cycprididae

Cyclocypridinae

Cyclocypris ovum (Jurine, 1820)

Cypridopsinae

Plesiocypridopsis newtoni (Brady and Robertson, 1870)

Potamocypris cfr villosa (Jurine, 1820)

$\begin{array}{lllllllll}+ & + \\ +\end{array}$

Eucypridinae 
with the Balkans, which constitute evidence of its shared geological history with the palaeo-Aegean area. However, these faunal affinities do not appear to include the calanoid fauna of Puglia, which belongs to a broader Mediterranean province (together with Sardinia and Sicily) rather than a separate one (Alfonso and Belmonte, 2011). In fact, apart from Hemidiaptomus ingens (Gurney, 1909) whose molecular lineage indicates that the specimens found in Puglia could belong to a separate species (Marrone et al., 2012), N. alluaudi is currently the only inland water calanoid species in the Italian context to be found exclusively in the Puglia faunal province.

\section{Remarks on the geographical distribution}

The distribution sites shown in Fig. 2 supply the cumulative and complete information derived from the available literature data on $N$. alluaudi, therefore they are indicative of the sum of sites where the species has been reported, rather than the actual current distribution of the species. Fig. 2 probably suffers the dearth of accurate studies at greater temporal and geographical scales. For all these reasons, a chronogeonemy of the species is difficult to set.

One of the most interesting aspects of Fig. 2 is the interpretation of the empty areas between groups of occurrence sites. While in some cases they may be explained by the scarcity of studies (i.e. parts of Northern Africa and the Middle East), in other cases they could be areas where the species has never been observed in spite of the high number of studies (i.e. Tunisia, France, Germany). These certified empty areas have led some authors (Miracle, 1982; Pretus, 1991) to speak about a disjunct distribution of the species. We agree with those authors who proposed a southern origin for the species (Miracle, 1982), but we do not share the idea that it is characterised by a disjunct distribution. Presumably, starting from Northern Africa, $N$. alluaudi could have spread via a stepping-stone mechanism into the Euro-Mediterranean and Turanian areas, favoured by its plastic ecological requirements.

The distribution map in the Iberian peninsula (Fig. 2) provides evidence of colonisation from the South (i.e. Africa) towards Western Europe. Like many other North African species, $N$. alluaudi could have easily colonised the Iberian peninsula by crossing the Gibraltar strait. In contrast, the Pyrenees constitute an insurmountable barrier preventing the spread of the species towards France and Central Europe.

The map (Fig. 2) also shows a plausible passage of the species out of Africa towards the Middle East and Eastern Europe through the Sinai peninsula. However, the doubtful records in Syria and Iran, together with the lack of further information, suggest that the eastward spread of the species was prevented by the Turkish-Iranian mountain chain (as with the Pyrenees in the west). The eastern expansion route appears less straightforward than the west- ern one and shows two alternatives: i) across the Sinai peninsula and along the eastern Mediterranean coast, or ii) from Cyrenaica to Crete and the Balkans across the Mediterranean sea. The latter is better documented in terms of the currently available data. Our findings in Puglia are thus assumed to be related to the expansion of the species to Eastern Europe.

The species' easternmost expansion route might have gone through Thrace and along the western and northern coastal lowlands of the Black sea towards the Ural mountains and the eastern coast of the Caspian sea (Turkmenistan). According to the currently available data, the species' eastward distribution does not go beyond Turkmenistan.

In contrast, expansion towards Northern Europe was prevented by the Carpathian mountains to the north-east, where the species was confined inside the Pannonian basin.

Mountains seem to have affected the distribution of $N$. alluaudi in different ways at different latitudes. At lower latitudes (Hoggar, Aïr mountains, Ennedi, Morocco) mountains represent a sort of refuge characterised by a Mediterranean climate, probably more suitable for the species. Conversely, at higher latitudes (the Pyrenees and Carpathians), mountains represent a sort of ecological barrier to the spread of the species.

The certified absence of the species from the central part of Europe (roughly from Denmark to Italy) and from most of the Mediterranean coastal areas of Africa (Algeria, Tunisia and most of Libya) makes identification of the species' chorotype somewhat difficult. In fact, this could be seen as the association of two different chorotypes: the Saharan chorotype (code 5.05 SAH sensu Vigna Taglianti et al., 1999) and the Turanic European Mediterranean chorotype (code 1.09 TEM sensu Vigna Taglianti et al., 1999). This association of chorotypes can in turn be interpreted as the consequence of the northward expansion of an African species following two different main routes. This pincer-like distribution pattern parallels that of the fairy shrimp Streptocephalus torvicornis (Dumont et al., 1995), a species often detected in the same crustacean communities of ponds with N. alluaudi (Alonso, 1998).

If climatic conditions have played a significant role in the distribution of $N$. alluaudi, then the climatic changes currently in progress could support further northward expansion. This hypothesis requires periodical monitoring on a larger scale.

\section{CONCLUSIONS}

The case of $N$. alluaudi raises problems related to our perception of the species' distribution, which is affected by our patchy knowledge of the fauna in broad geographical contexts and probably does not reflect the real distribution of the species. In addition, online databases present a twofold problem: they often report incomplete informa- 
tion without sound validation of data and the cumulative data may overestimate the current species distribution, as this might vary with time.

The first record of $N$. alluaudi in Italy fills a significant gap in its known distribution, which is highly peculiar among the inland water Calanoida of the Palaearctic realm. If it is true that $N$. alluaudi is a species of southern origin [as hypothesised by Miracle (1982)], then the Saharan populations could be older and the European populations younger. In addition, the Iberian population might have a different origin from Eastern-European and Turanian populations. Molecular tools may help to validate these hypotheses in future research by offering a solid interpretation of both the species' distribution and its life history.

\section{ACKNOWLEDGMENTS}

This research was partly financed by the Fondazione Cassa di Risparmio di Puglia Banking Foundation and partly by the Alta Murgia National Park. Our thanks to Dani Boix, Henri J. Dumont, M. Ruşen Ustaoğlu, Kata Kovács, Federico Marrone, Lana Ong, Joan Llouís Pretus, Nancy Rayner, Larysa Samchyshyna, Boris Sket and Igor Stanković for supplying references and information on sites. Our thanks to Fabio Stoch for the identification of Cyclopoida and to Serena Guindani and Giampaolo Rossetti for the identification of Ostracoda. We also thank Noyan Yilmaz and Riccardo Russo for their help in the collection of samples.

\section{REFERENCES}

Alonso M, 1996. [Crustacea, Branchiopoda]. [Book in Spanish]. Museo Nacional de Ciencias Naturales ed., Madrid: 486 pp.

Alonso M, 1998. [Las lagunas de la Espaňa peninsular]. [Article in Spanish]. Limnética 15:1-176.

Alfonso G, Belmonte G, 2008. Expanding distribution of Boeckella triarticulata (Thomson, 1883) (Copepoda: Calanoida: Centropagidae) in Southern Italy. Aquat. Invas. $3: 247-251$.

Alfonso G, Belmonte G, 2011. Calanoida (Crustacea Copepoda) from the inland waters of Apulia (South-Eastern Italy). J. Limnol. 70:57-68.

Alfonso G, Belmonte G, Ernandes P, Zuccarello V, 2011. [Stagni temporanei mediterranei in Puglia]. [Book in Italian]. Grifo ed., Lecce: 143 pp.

Barrois T, 1891. [Sur trois Diaptomus nouveaux des environs du Caire]. [Article in French]. Rev. Biol. N. Fr. 3:277-281.

Belmonte G, Alfonso G, Moscatello S, 2006. Copepod fauna in small ponds of the Pollino National Park (South Italy), with notes on seasonality and biometry of species. J. Limnol. 65:107-113.

Borutzky EV, Stepanova LA, Kos MS, 1991. [Key of freshwater Calanoida of the USSR]. [Book in Russian]. Nauka, St. Petersburg: $504 \mathrm{pp}$.

Boxshall GA, Halsey SH, 2004. An introduction to copepod diversity. Ray Society Publ., London: 966 pp.

Boxshall GA, Jaume D, 2000. Making waves: the repeated col- onization of fresh water by copepod crustaceans. Adv. Ecol. Res. 31:61-79.

Brtek J, 1977. [Anostraca, Notostraca, Conchostraca a Calanoida Slovenska. II Cast]. [Article in Slovak]. Acta Rer. Natur. Mus. Nat. Slov. Bratislava 23:117-150.

Daday E, 1890. [A Magyarországi Diaptomus-fajok ätnézete. Conspectus Diaptomorum faunae hungaricae]. [Article in Hungarian and Latin]. Természetrajzi Füzetek 13:114-143.

Dahlgren R, Van Nieuwenhuyse, Litton G, 2004. Transparency tube provides reliable water-quality measurements. Calif. Agr. 58:149-153.

Damian-Georgescu A, 1966. [Copepoda. Calanoida (Forme de apă dulce)]. [Book in Rumanian]. Bucharest, Academiei RSR ed.: 128 pp.

Defaye D, Cuoc C, Brunet M, 2000. Genital structures and spermatophore placement in female Paradiaptominae (Copepoda, Calanoida, Diaptomidae). J. Crustacean Biol. 20: 245-261.

Demeter L, Marrone F, 2009. Updated checklist and distribution of the inland-water calanoid copepods (Copepoda: Calanoida) of Romania. North-West. J. Zool. 5:370-378.

Dumont HJ, 1979. [Limnologie van Sahara en Sahel]. [Degree Thesis in French]. Rijksuniversiteit ed., Ghent: 557 pp.

Dumont HJ, Laureys P, Pensaert J, 1979. Anostraca, Conchostraca, Cladocera and Copepoda from Tunisia. Hydrobiologia 66:259-274.

Dumont HJ, Mertens J, Maeda-Martinez A, 1995. Historical and morphological differentiation of Streptocephalus torvicornis (Waga) since the Würm II-glaciation. Hydrobiologia 298: 281-286.

Dussart B, 1967. [Les copépodes des eaux continentales d'Europe Occidentale. I. Calanoïdes et Harpacticoïdes]. [Book in French]. N. Boubée et Cie, Paris: 500 pp.

Dussart B, 1989. [Crustacés Copépodes Calanoïdes des eaux intérieures africanes]. [Article in French]. Crustaceana 15:1-205.

Dussart B, Defaye D, 1983. [Répertoire mondial des Crustacés Copépodes des eaux intérieures. Les Calanoïdes]. [Book in French]. Centre national de la recherche scientifique ed., Paris: 224 pp.

Dussart B, Defaye D, 2002. World directory of calanoida copepoda of inland waters. I. Calaniformes. Backhuys Publ., Leiden: $276 \mathrm{pp}$.

Einsle U, 1993. [Crustacea Copepoda. Calanoida und Cyclopoida. Süsswasserfauna Mitteleuropas, 8/4-1]. [Book in German]. Gustav Fisher Verlag, Jena: 206 pp.

Ekman S, 1904a. [Cladoceren und freilebende Copepoden aus Ägypten und dem Sudan], p. 1-18. [Chapter in German]. In: L.A. Jägerskiöld (ed.), Results of the Swedish zoological expedition to Egypt and the White Nile, 1901. Library of the Royal University of Uppsala ed.

Ekman S, 1904b. [Die Phyllopoden, Cladoceren und freilebenden Copepoden der nord-schwedischen Hochgebirge. Ein Beitrag zur Tiergeographie, Biologie und Systematik der arktischen, nord- und mittel-Europäischen Arten]. [Article in German]. Zool. Jahrb. Allg. Zool. 21:1-170.

European Commission, 1992. Council Directive of 21 May 1992 on the conservation of natural habitats and of wild fauna and flora, 92/43/EC. In: Official Journal, L 206, 22/07/1992, pp. 7-50.

François Y, 1949. [Sur les Copépodes des eaux douces du 
Maroc]. [Article in French]. B. Soc. Zool. Fr. 74:191-198.

Gauthier, H. 1928. [Recherches sur la faune des eaux continentales de l'Algérie et de la Tunisie]. [Book in French]. Minerva ed., Algiers: 419 pp.

Gauthier H, 1931. [Faune aquatique du Sahara central. Récoltes de M. L. G. Seurat au Hoggar en 1928]. [Article in French]. Bull. Soc. Hist. Nat. Afr. N. 22:350-400.

Gauthier H, 1933. [Faune aquatique du Sahara central. Récoltes de M. Th. Monod dans l'Emmidir et l'Ahnet]. [Article in French]. Bull. Soc. Hist. Nat. Afr. N. 24:127-132.

Gauthier H. 1938. [La vie aquatique dans les déserts subtropicaux], p. 107-120. In: L. Aufrére, F.-S. Bodenheimer, A. Chevalier, L. Chopard, L. Emberger, H. Foley, F.S. Bodenheimer (eds.), [La vie dans la région désertique nord-tropicale de l'ancien monde]. [Book in French]. Lechevalier.

Gaviria S, Herzig A, Forrò L, 2002. Crustacea: Copepoda: Calanoida, p. 1-3. In: O. Moog (ed.), Fauna Aquatica Austriaca. III. Wasserwirtschaftskataster, Bundesministerium für Landund Forstwirtschaft, Umwelt und Wasserwirtschaft ed.

Giesbrecht W, Schmeil O, 1898. [Copepoda. I. Gymnoplea]. [Book in German]. Verlag Von Friedländer und Sohn.

Gjorgewič J, 1907. [Les organismes du plancton des grands lacs de la peninsule Balkanique]. [Article in French]. Mém. Soc. Zool. Fr. 20:5-19.

Guerne J, Richard J, 1890. [Description du Diaptomus Alluaudi, n. sp. recueilli par M. Alluaud dans un réservoir d'eau douce à Lanzarote (Canaries)]. [Article in Latin and French]. B. Soc. Zool. Fr. 15:198-200.

Guerne J, Richard J, 1891. [Synonymie et distribution géographique de Diaptomus Alluaudi]. [Article in French]. B. Soc. Zool. Fr. 16:213-217.

Guerne J, Richard J, 1896. [Première liste des Copépodes et Cladocères d'eau douce du Portugal]. [Article French]. B. Soc. Zool. Fr. 21:157-159.

Gurney R, 1909. On the fresh-water Crustacea of Algeria and Tunisia. J. R. Microsc. Soc. 29:273-305.

Gurney R, 1929. Notes on the Diaptomidae of South Africa. Ann. Mag. Nat. Hist. 4:572-584.

Jaume D, 1989-1990. [Calanoides (Crustacea: Copepoda) de les aigües continentals Baleáriques]. [Article in Catalan]. Boll. Soc. Hist. Nat. Balears 33:207-219.

Kiefer F, 1927. [Beitrang zur Kenntnis der freilebende Copepoden Ungarns]. [Article in German]. Arch. Balat. Budapest 1:400-420.

Kiefer F, 1932. [Versuch eines Systems der Diaptomiden (Copepoda Calanoida)]. [Article in German]. Zool. Jahrb. Abt. Anat. Ontog. Tiere 63:451-520.

Kiefer F, 1958. [Diaptomiden (Crustacea Copepoda) aus dem Gebiet von Tassili n'Ajjer (Zentral-Sahara)]. [Article in German]. Trav. Inst. Rech. Sahar. 3:111-126.

Kiefer F, 1978a. [Das Zooplankton der Binnengewässer. Freilebende Copepoda. Die Binnengewässer. 2]. [Book in German]. E. Schweizerbart'sche Verlagbuchhandlung, Stuttgart: $343 \mathrm{pp}$.

Kiefer F, 1978b. [Zur Kenntnis der Copepodenfauna aegyptischer Binnengewaesser]. [Article in German]. Arch. Hydrobiol. 84:480-499.

Margalef R, 1953. [Los crustáceos de las aguas continentales ibéricas]. [Book in Spanish]. Ministerio de Agriculture, Dirección General de Montes, Caza y Pesca Fluvial, Instituto
Forestal de Investigaciones y Experiencias ed., Madrid: 243 pp.

Margalef R, 1956. [La vida en las aguas de elevado residuo salino de la provincia Zamora]. [Article in Spanish]. P. Inst. Biol. Apl. 24:123-137.

Margaritora FG, 1985. [Cladocera]. [Book in Italian]. Calderini ed., Bologna: 389 pp.

Marrone F, Naselli-Flores L, 2005. First record of a representative of the subfamily Paradiaptominae (Copepoda Calanoida Diaptomidae) in Italy: Metadiaptomus chevreuxi (Guerne and Richard, 1894). J. Limnol. 64:89-92.

Marrone F, Barone R, Naselli-Flores L, 2006a. Ecological characterization and cladocerans, calanoid copepods and large branchiopods of temporary ponds in a Mediterranean island (Sicily, southern Italy). Chem. Ecol. 22 (Suppl. 1):181-190.

Marrone F, Castelli G, Barone R, Naselli-Flores L, 2006b. Ecology and distribution of calanoid copepods in Sicilian inland waters (Italy). Verh. Internat. Verein. Limnol. 29:2150-2156.

Marrone F, Alfonso G, Miserocchi D, Lo Brutto S, 2011. First record of Hemidiaptomus (Gigantodiaptomus) superbus (Schmeil, 1895) in Italy, with notes on distribution and conservation status (Copepoda, Calanoida, Diaptomidae), J. Limnol. 70:149-155.

Marrone F, Lo Brutto S, Hundsdoerfer AK, Arculeo, 2012. Overlooked cryptic endemism in copepods: Systematics and natural history of the calanoid subgenus Occidodiaptomus Borutzky 1991 (Copepoda, Calanoida, Diaptomidae). Mol. Phylogenet. Evol. 66:190-202.

Meisch C, 2000. Freshwater Ostracoda of Western and Central Europe. Spektrum Akademischer Verlag, Heidelberg: 522 pp.

Minelli A, Ruffo S, Vigna Taglianti A, 2006. The Italian faunal provinces. Mem. Mus. Civ. St. Nat. Verona 17:37-39.

Miracle MR, 1982. Biogeography of the freshwater zooplankton communities of Spain. J. Biogeogr. 9:445-467.

Naidenow W, 1966. [Katalog der Copepodenfauna Bulgariens]. [Article in German]. Izv. Zool. Inst. Sof. 21:109-138.

Naidenow W, 1973. [Biozönologische Untersuchungen der stehenden Gewässer im "Ludogorie" (Nordwest Bulgarien)]. [Article in Bulgarian]. Izv. Zool. Inst. Sof. 38:149-181.

Ortiz E, 1957. [Diaptómidos des las aguas continentales espanolas (Crustacea Copepoda)]. [Article in Spanish]. Bol. R. Soc. Esp. Hist. Nat. Biol. 55:391-398.

Pesce GL, Maggi D, 1981. [Cyclopides et calanoïdes des phréatiques de la Grèce meridionale et insulaire (Crustacea: Copepoda)]. [Article in French]. Ecol. Mediterranea 7:163-182.

Petkovski TK, 1983. [Calanoida (Crustacea - Copepoda). Fauna na Makedonija. V]. [Book in Macedonian]. Prirodonaučen Muzej na Makedonija ed., Skopje: 182 pp.

Pljakic MA, Zivkovic A, 1958. [Einige Elemente der Copepoden und Cladocerenfauna in periodischen Gewässern des karstes]. [Article in German]. Zool. Anz. 21:516-524.

Pretus JL, 1991. [Estudio taxonómico, biogeográfico y ecológico de los crustáceos epigeos e hipogeos de las Baleares (Branchiopoda, Copepoda, Mystacocarida y Malacostraca)]. [PhD Thesis in Catalan]. University of Barcelona ed., Barcelona: $523 \mathrm{pp}$.

Rayner N, 1992. Revision of the of the freshwater diaptomid genus Lovenula (Crustacea, Copepoda) in Africa. Ann. S. Afr. Mus. 101:297-332.

Rayner NA, 1999. Copepoda: Calanoida: Diaptomidae: Para- 
diaptominae. guides to the identification of the microinvertebrates of the continental waters of the world 15. Backhuys Publ., Leiden: 122 pp.

Rayner NA, 2000. Distribution and biogeography of the Paradiaptominae (Copepoda: Calanoida: Diaptomidae). Afr. J. Aquat. Sci. 25:93-97.

Richard J, 1893. [Copépodes recueillis par M.le Dr. Th Barrois en Egypte, en Syrie et en Palestine (mars-juin 1890)]. [Article in French]. Rev. Biol. N. Fr. 10:3-36.

Rose M, Vaissière R, 1952/53. [Catalogue préliminaire des copépodes de l'Afrique du Nord]. [Article in French]. Bull. Soc. Hist. Nat. Afr. N. 43:113-136.

Samchyshyna LV, 2011. Faunistical overview of calanoid copepods (Crustacea) from continental waters of Ukraine. Vestn. Zool. 45:299-305.

Stella E, 1984. [Copepoda: Calanoida]. [Book in Italian]. Calderini ed., Bologna: 101 pp.

Stoch F, 2006. Crustacea Copepoda Calanoida. Mem. Mus. Civ. St. Nat. Verona 17:91-92.

Tollinger MA, 1911. [Die geographische Verbreitung der Diaptomiden und aderer süss- und brackwasser Gattungen aus der Familie der Centropagiden]. [Article in German]. Zool. Jahrb. Syst. 30:1-302.

Turki S, Turki B, 2010. Copepoda and Branchiopoda from Tunisian temporary waters. Int. J. Biodiv. Cons. 2:86-97.
Ulomsky SM, 1941. [Über eine neue Arctodiaptomus-Art (Copepoda) aus der Krim (USSR)]. [Article in German]. Zool. Anz. 134:115-122.

Ustaoğlu MR, 2004. A check-list for zooplankton of Turkish inland waters. E.U. J. Fish. Aquat. Sci. 21:191-199.

Vigna Taglianti A, Audisio PA, Biondi M, Bologna MA, Carpaneto GM, De Biase A, Fattorini S, Piattella E, Sindaco R, Venchi A, Zapparoli M, 1999. A proposal for a chorotype classification of the Near East fauna, in the frame work of the Western Palearctic region. Biogeographia 20:31-59.

World Register of Marine Species, 2012. Neolovenula alluaudi (Guerne and Richard, 1890). Available from: http://www. marinespecies.org/aphia.php? $\mathrm{p}=$ taxdetailsandid $=366061$ Accessed: 25/09/2012.

Yevdokimov NA, Yermokhin MV, 2009. Zooplankton Crustaceans of ephemeral waterbodies on the territory of various natural zones in Saratov Oblast. Inland Water Biol. 2:59-66.

Zaitsev YP, Alexandrov BG, 1998. Black sea biological diversity: Ukraine. 7. United Nations Publ., New York, NY: 351 pp.

Zito G, Ruggiero L, Zuanni F, 1991. [Aspetti meteorologici e climatici della Puglia], p. 43-73. In: Piccione V. and Antonelli C. (eds.), Proc. of $1^{\text {st }}$ Workshop [Progetto Strategico C.N.R. Clima Ambiente e Territorio nel Mezzogiorno]. [Book in Italian]. Taormina, 11-12 Dec. 1989. CNR Publ. 